\title{
Information Technology Enterprise Architecture Planning in the National and Political Unity Agency "KESBANGPOL" of Salatiga City Using Enterprise Architecture Planning (EAP)
}

\author{
Chevin Robert Warint \\ Information System, \\ Kristen Satya Wacana University, \\ Salatiga, 50715, Indonesia \\ 682015059@student.uksw.edu
}

\author{
Yani Rahardja \\ Information System, \\ Kristen Satya Wacana University, \\ Salatiga, 50715, Indonesia \\ yani.rahardja@uksw.edu
}

\author{
Melkior N.N. Sitokdana* \\ Information System, \\ Kristen Satya Wacana University, \\ Salatiga, 50715, Indonesia \\ melkior.sitokdana@uksw.edu \\ *Corresponding author
}

\begin{abstract}
The National and Political Unity Agency "KESBANGPOL" of Salatiga City is a government agency tasked with overseeing community activities in Salatiga City. In designing the information system architecture of the National Unity and Political Body "KESBANGPOL" of Salatiga City, the Enterprise Architecture Planning "EAP" methodology is used. Enterprise Architecture Planning "EAP" is a tool developed to build an enterprise architecture that harmonizes the three types of architecture in its development, namely data architecture, application architecture, and technology architecture. Based on this research it was found that there was no adequate administrative information system. The condition of the computer network owned by The National and Political Unity Agency "KESBANGPOL" has 1 internetconnected to 1 server. 1 The server is connected to 2 Routers, where 2 Routers are connected to 23 PC Servers and also connected to 20 printers. Based on the application system architecture, the mapping process of infrastructure components can be carried out. These infrastructure facilities are still inadequate for The National and Political Unity Agency "KESBANGPOL" with community service activities in Salatiga City which are very dense, so it is necessary to add computer and PC networks in order to facilitate service activities.
\end{abstract}

Abstract-Planning, Enterprise Architecture, Enterprise Architecture Planning (EAP), National and Political Unity Agency, Salatiga.

\section{INTRODUCTION}

The National and Political Unity Agency "KESBANGPOL" of Salatiga City has implemented various information technology facilities and information systems, but it does not yet have a blueprint or strategic plan as a reference for its implementation, therefore research on Enterprise Architecture Planning (EAP) is needed, then briefly, EAP. The process of identifying application portfolios that will assist organizations in carrying out business plans and realizing business goals is carried out using the EAP method. Research on enterprise architecture design using Enterprise Architecture Planning (EAP) is not a new topic, therefore this study will cite several previous studies as a reference for this research, including the following (Kustiyahningsih, 2013).

The research entitled the application of the Enterprise Architecture Planning (EAP) Method in Making an Academic System Blueprint. From this research, it was found that after implementing the Enterprise Architecture Planning (EAP) method in making the blueprint of the ITENAS academic system, important aspects were found in making this academic system blueprint. These aspects are system business processes, parties involved in the system, data required by the system, and matriculation such as process vs business, process vs organization, system vs organization, and process vs data class. Based on the stages that have been carried out in this research, the Enterprise Architecture Planning (EAP) methodology can be applied to the creation of the "ITENAS" academic system blueprint (Subagio, 2017).

The research entitled "Designing Enterprise Architecture Planning (EAP) in Asset Management Process with Zachman Framework (Case Study of PT.XYZ Facility Management Division)" [4]. Discussing the relationship between existing architectures is important for Enterprise Architecture Planning (EAP). In this modeling oriented to business needs and how to implement the architecture that is made to support the achievement of asset management objectives at PT. XYZ so that asset management is maximized. Enterprise Architecture Planning (EAP) is a collection of architectural and strategic fields that include information, business systems, and engineering architecture (Tyas, 2013).

Enterprise Architecture Planning (EAP) is also a modern approach to planning data quality in order to achieve the Information Systems mission in the asset management unit. The design results that have been made include data architecture, application architecture, and technology architecture, application portfolio. This research produces a blueprint (blueprint) for the design of 
the Enterprise Architecture Planning (EAP) of asset management (Irmayanti, 2018).

Joko Triloka's research entitled "Architectural Modeling to Support Integrated Information Systems in the Academic Field Using Enterprise Architecture Planning". This method can be used as a guide for a tool to plan, design, develop and implement an information system architecture for an organization and divide it into 3 (three) important stages in relation to enterprise architecture modeling in case study colleges at UIN Sunan Kalijaga Yogyakarta, the architecture described namely regarding the data, applications, and technology needed to support activities and organizations in the academic section at UIN Sunan Kalijaga Yogyakarta.

Another research by (Kurniawan, 2011) entitled "Enterprise Architecture Planning Information Systems in Private Higher Education with Zachman Framework". Enterprise Architecture Planning (EAP) as a method or frame of reference for building an information architecture. EAP is an architectural planning method that is oriented towards business needs which consists of data architecture, applications, and technology as well as an implementation plan of the architecture that has been created to support business activities for the achievement of the organization's mission. The purpose of this research is to have a good enterprise architecture design that can be used to develop information systems, namely by building an Enterprise Architecture Planning using the Zachman Framework which will produce a structured information system implementation roadmap (Andy, 2019).

\section{LITERATURE REVIEW}

Information technology is a means and infrastructure (hardware, software, user) systems and methods for obtaining, sending, processing, interpreting, storing, organizing, and using data meaningfully (Bambang Warsita, 2008). Information technology is defined as knowledge in the field of computer-based information and its development is very rapid (Lantip and Rianto, 2011). Information technology is a technology used to process data (Hamzah B. Uno and Nina Lamatenggo, 2011).

Enterprise architecture is a coherent unit of principles, methods and models used in the design and realization of the organizational structure, business processes, information systems and infrastructure of a company (Lankhorst 2005). Enterprise architecture is a complete expression of the company; The master plan acts as a collaborative force between aspects of business operations such as business terms, organizational structures, processes and data; automation aspects such as information systems and databases, and enabling future technology infrastructure from businesses such as computers, operating systems, and networks (IFEAD, 2011). Enterprise Architecture Planning (EAP) is a method used to build an information architecture (Spewak, 2006). The stages of developing an Enterprise Architecture Planning (EAP) are the stages to start, the stage to understand the current condition, and the stage of compiling a plan in achieving a vision for the future components of Enterprise Architecture Planning (EAP) are shown in Picture 1.

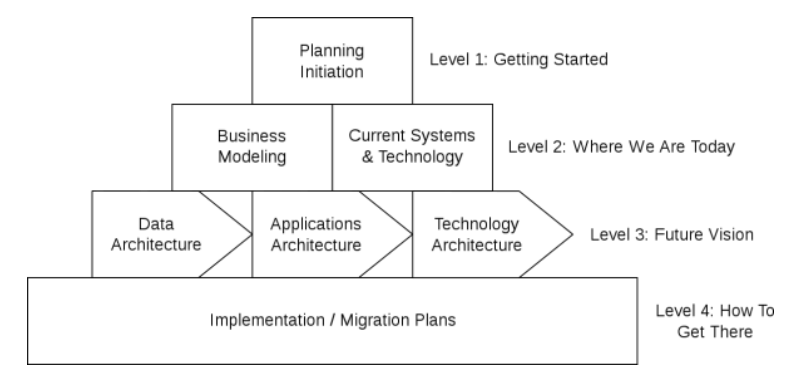

Picture 1. Future Components of Enterprise Architecture Planning $(E A P)$

\section{A. Layer 1. Planning Initialization}

This stage aims to identify the rules that are referenced in relation to enterprise architecture planning for information system development in order to determine the scope of the enterprise, vision, mission, adoption of planning methodologies and form a planning team so that the EAP project is targeted, completed on time and has members qualified team (Krisetya, 2014).

\section{B. Layer 2. Overview of the Current State of the Enterprise}

a) Business Process Modeling.

This stage aims to build a knowledge base about the business and information that enterprises use today. This stage is the process of defining business in order to provide a model for the enterprise business. Consistent, comprehensive, and complete so that it can be used to define architectures and implementation plans. Business modeling is done by identifying and documenting the organizational structure and defining key business areas using a value chain model to highlight activities in the business. At this stage, a matrix of relationships between business functions and organizational units is also made to find out the responsibilities of each organizational unit for a business function.

b) Current Systems and Technologies.

The purpose is to identify and document the application systems and technology platforms that enterprises use in supporting business functions today because enterprises that have been running generally already have systems and technology for their information system applications. The result of documentation is referred to as the Information Resource Catalog (IRC) or also known as the Systems Inventory. IRC does not describe each system in detail, only in summary.

\section{Layer 3. Overview of Future Enterprise Plans}

a) Data Architecture

This stage aims to identify and define the types of main data or data entities needed for an enterprise to support the business functions that have been defined in the business modeling stage and then 
relate these data entities to enterprise business functions. Data architecture is an enterprise architecture for information systems architecture, namely the data column (what) in the Zachman framework. Following are the steps taken in designing the data architecture :

1. List the candidate data entities. Its purpose is to identify all potential data entities needed to support the business. This can be done by taking into account the data requirements of each defined business process.

2. Create a diagram of the relationship between data entities. A data entity can support more than one business function area and is not independent but has dependencies and relationships with other data entities. The EAP approach takes the dependencies and relationships between these data entities to underlie the development of an enterprise architecture. This considers that applications are closely related to databases whereas a database consists of a collection of data entities with their relationships and dependencies, therefore data entities need to be assembled according to dependencies and their relationships in the context of the functional areas they support. Modeling to describe the relationship between data entities using the Entity-Relationship Diagram (ERD). The results of E-RD modeling for each function area complement the Zachman framework on the owner's perspective row and data column.

3. Associate data entities with business functions. Each defined data entity is associated with a business function area. The relationship between the data entity and the business function area is in terms of processing and using data for the purpose of meeting business function objectives. This relationship is defined through a relationship matrix between data entities and business functions. Each cell in the matrix to determine entity data is created (C), which is a function for creating data, read / reference (R) is a function that uses data and updates (U) is a function that changes or updates data.

b) Application Architecture

This stage aims to identify and define the main types of applications needed to manage data and support enterprise business functions, then relate the applications to enterprise business functions. Application architecture is not a system design but it defines what applications are needed to manage data and provide information for users to perform business functions. The steps in designing an application architecture are :

1. Create a list of candidate applications and application definitions. Once the business functions are defined and the data architecture for the future is built, the business drives and data drives are directed to define and define application applications. This step aims to identify every possible application required for data management and business function support. The first step in this stage is to make an inventory of the candidate application candidates needed to support business processes and manage data for the future. Candidates for application candidates can be obtained by reviewing the catalog of information resources and accommodating various inputs from the actual needs of enterprise units as well as by adapting the development of information system applications.

2. Relate applications with business functions. This step aims to determine the business functions that the application directly supports or accommodations.

3. Perform impact analysis on current applications. This step is a determination of options to keep using the application, modify, or replace the legacy system.

c) Technology Architecture

This stage aims to identify and define the technological principles needed to provide an environment that supports applications on prestructured application architectures in managing data and supporting business functions. Technology architecture is the definition of technology that will support business functions by providing a data-sharing environment. Following are the steps in designing a technology architecture :

1. Identify the technology principles that will be used. This step aims to identify the principles that must be considered for selecting the technology platform needed by enterprises.

2. Technology conceptual configuration. This step is built based on the needs of data distribution strategies and applications as well as the need for data sharing among organizational units with due regard to business locations.

\section{Layer 4. Implementation Plan}

This stage aims to compile and prepare a recommendation for an implementation plan based on the architecture that has been made. The steps in the implementation plan stage are.

a) Defines the order of priority for application development. This step is implemented from many applications that have been defined using application principles that create (create) data first implemented before applications that change (update) data or use (reference) data.

b) Make estimates of the implementation. This step aims to estimate the needs when the implementation is carried out. 
c) Make planning conclusions. The planning conclusion is the final report of the enterprise architecture planning in the form of a blueprint.

\section{RESEARCH METHODS}

This research using a qualitative approach. Qualitative research is research that is used to examine the conditions of natural objects, where the researcher is a key instrument (Sugiyono, 2005). The difference with quantitative research is that this research departs from data, utilizes existing theories as explanatory material, and ends with a theory. According to Moleong (2005: 6), qualitative research is research that intends to understand the phenomena experienced by research subjects such as behavior, perception, motivation, action, etc. in a holistic manner, and by means of descriptions in the form of words and language. a special context which is natural and by making use of various natural methods see in picture 2 .

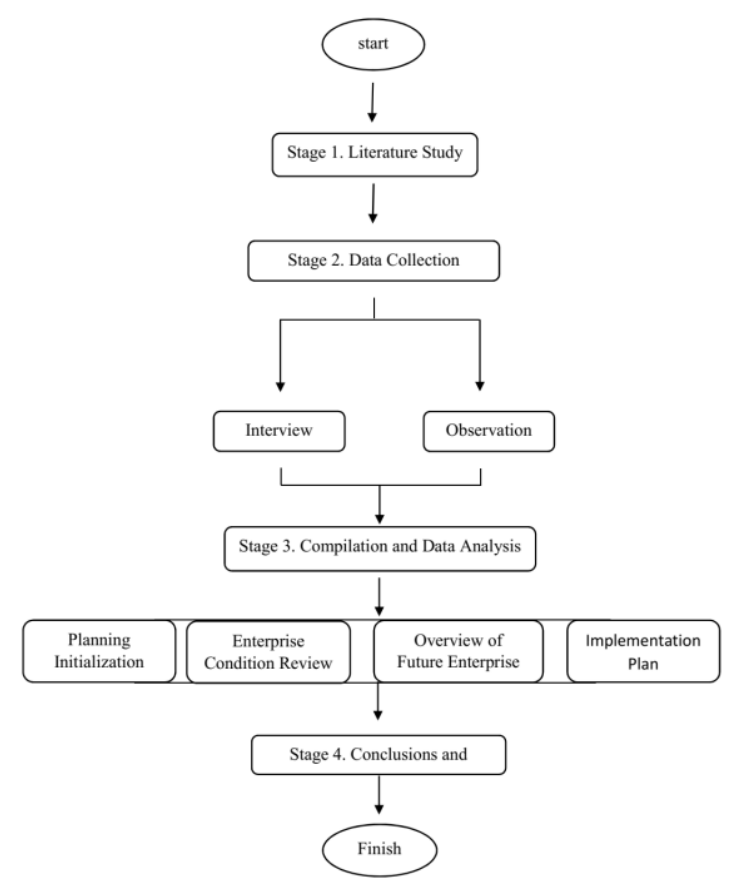

Picture 2. Research Stages

Stage 1. Literature study is the initial stage of the described research stages. In this stage, a search for books and journals related to EAP is carried out. These books and journals become the author's references in this study so that the authors can understand the concept of EAP.

Stage 2. Data collection was carried out by means of interviews and observations. The interview was conducted with Mr. Paiman as the supervisor of KP's children. Observations were carried out for 2 calculated months from September-October 2019. Input in this stage is an interview and observation guide based on the guidelines and the output of this stage is the data needed to support the planning of making EAP.
Stage 3. From the data collected, data preparation and analysis were carried out. In accordance with the EAP stages, starting from initial analysis planning to implementation plans.

Stage 4. Based on the results of the analysis and discussion conclusions and suggestions will be drawn for further research.

\section{RESULTS AND DISCUSSION}

KESBANGPOL Salatiga City is a government agency assigned to oversee the activities of community activities in Salatiga City such as political activities, city culture, the status of foreign citizens who enter the city of Salatiga. The process of identifying application portfolios that will assist organizations in carrying out business plans and realizing business goals is carried out using the EAP method. Some of the fields include the secretariat, politics, national insight, arts and cultural resilience, national vigilance at KESBANGPOL, Salatiga.

From the identification of the development of fields in KESBANGPOL of Salatiga city, the determination of the scope of the enterprise that will be made of the architecture. In order for this scope to run effectively and efficiently, an enterprise information system is needed to carry out business functions capable of providing data and information to carry out business activities in providing good service to its users (Suryana, 2012).

The methodological approach uses EAP methodology. EAP is a method developed for building an enterprise architecture. The stages of EAP development are the stage to start, the stage to understand the current condition, the stage of defining a vision for the future, and the stage of preparing a plan in achieving a vision for the future. The EAP method harmonizes the three types of architecture in its development. Namely, information architecture, application architecture, and technology. The EAP methodology has four stages that will be carried out in 7 steps, namely planning initialization, modeling business processes and reviewing current systems and technology, designing data architecture, application architecture, and technology architecture, and implementation plans (Hidayat, 2017).

Business modeling is done by identifying and documenting the organizational structure, identifying and defining business functions by creating a business model using the value chain (chain), and making relationships between functions and company units. This is done to provide a knowledge base that can be used to define architectural plans.'

\section{A. Business Architecture}

Designing business architecture in Enterprise Architecture Planning (EAP) at the National and Political Unity Agency "KESBANGPOL" Salatiga City has main activities and supporting activities. The definition of KESBANGPOL business process is illustrated using value chain analysis as shown in Picture 3. 


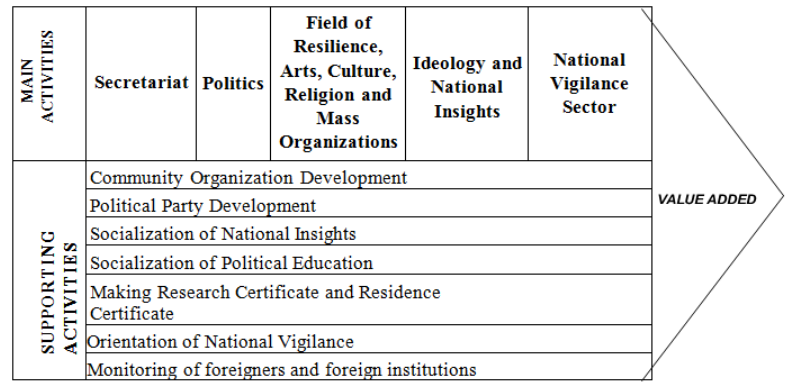

Picture 3. Business Architecture

The business process at KESBANGPOL has several stakeholders. The following are stakeholders who have an interest in the main and supporting business processes, namely :

a) KESBANGPOL, consisting of Head of Agency, Secretary of Agency, Head of Division, Head of Sub. Field, and Staff.

b) Students, Lecturers, Students, Teachers, Political Party Administrators, Community Organization Administrators, TNI / Polri, Teachers and the general public.

Explanation of the relationship between stakeholders and activities in the organization is shown in Table 1.

Table 1. Stakeholder Relationship with Organizational Activities

\begin{tabular}{|c|c|c|}
\hline Stakeholders & Kesbangpol & Public \\
\hline $\begin{array}{ll}\text { Main Activities: } \\
\text { - } & \text { Politics } \\
\text { - } & \text { Field of Resilience, Arts, Culture, } \\
& \text { Religion and Mass Organizations } \\
\text { - } & \text { Ideology and National Insights } \\
- & \text { National Vigilance Sector } \\
- & \text { Secretariat }\end{array}$ & $\begin{array}{l}\text { Head of Division, Head } \\
\text { of Sub. Field, and Staff } \\
\text { Employees }\end{array}$ & $\begin{array}{l}\text { Students, Lecturers, Students, } \\
\text { Teachers, Political Party } \\
\text { Administrators, Community } \\
\text { Organization Administrators, } \\
\text { TNI / Polri, Teachers and the } \\
\text { general public }\end{array}$ \\
\hline $\begin{array}{ll}\text { Supporting Activities: } \\
- & \text { Community Organization } \\
& \text { Development } \\
- & \text { Political Party Development } \\
- & \text { Socialization of National Insights } \\
- & \text { Socialization of Political Education } \\
- & \text { Making Research } \\
& \text { Certificate and Residence } \\
& \text { Certificate } \\
- & \text { Orientation of National Vigilance } \\
- & \text { Monitoring of foreigners and } \\
& \text { foreign institutions }\end{array}$ & $\begin{array}{l}\text { Head of Division, Head } \\
\text { of Sub. Field, and Staff } \\
\text { / Employees }\end{array}$ & $\begin{array}{lr}\text { Students, } & \text { Lecturers, } \\
\text { Students, } & \text { Teachers, Political } \\
\text { Party Administrators, } \\
\text { Community Organization } \\
\text { Administrators, TNI / Polri, } \\
\begin{array}{l}\text { Teachers } \\
\text { public }\end{array}\end{array}$ \\
\hline
\end{tabular}

\section{B. Information Architecture}

At the Information Systems Architecture stage, the information system used in KESBANGPOL is defined, namely: KESBANGPOL has several types of applications that are used in the activities performed (AlSoufi, 2012). Some applications that have been used are shown in Table 2 below.
Table 2. Application on KESBANGPOL

\begin{tabular}{|c|c|}
\hline IT name & IT users \\
\hline Filing System & Archives Section \\
\hline Staffing System & Personnel department \\
\hline Leave system & Leave section \\
\hline Financial System & Financial department \\
\hline Procurement Application System & Procurement Application Section \\
\hline Performance System & Performance part \\
\hline
\end{tabular}

The detailed definition of each business function that has been identified described in the business function can be described with a hierarchical chart of functions according to the business processes in KESBANGPOL which have been discussed can be simplified into an application architecture which can be described as a model in Picture 4.

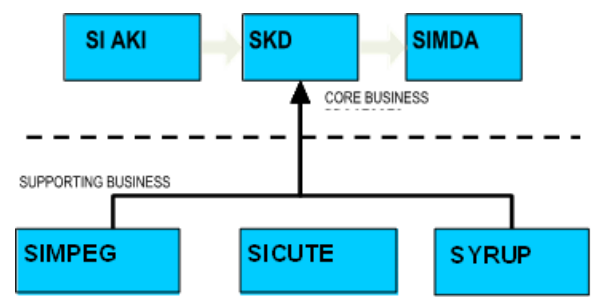

Picture 4. KESBANGPOL Application Architecture

Information of Figure 4
SI AKI
: Performance Information System
SKD : Regional Archives Information System
SIMDA : Financial Information Systems
SIMPEG : Information Systems Personnel Management
SI CUTE : : Leave Information System
SYRUP : Procurement Application Information System

Application architecture is identified based on :

a) Information needs to support decision making in every business function.

b) The need for exchange of information between business functions.

c) The need for exchange of information between business functions.

d) The needs and exchange of information, in general, have been described in the description of business process modeling so that the determination of the application architecture used to help the main business functions and supporting organizations can be defined using the Application Portfolio, while the application system architecture can be modeled using the application landscape, which describes the close relationship between systems applications that can be seen in Picture 5 below : 


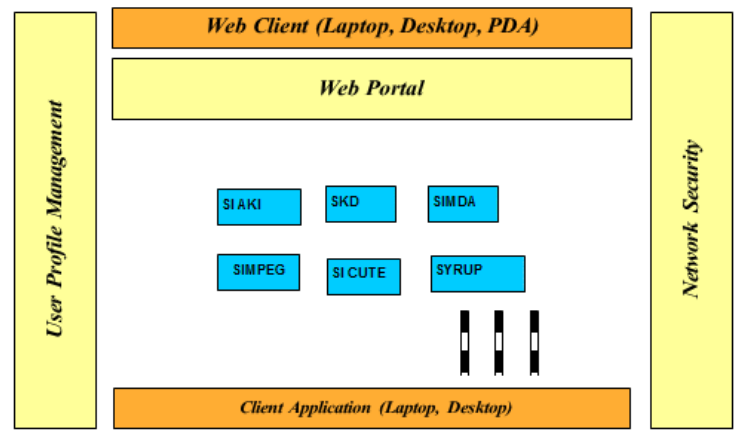

Picture 5. Application System Architecture

C. Information Architecture

Use of technology in KESBANGPOL is shown in Table 3 below :

Table 3. Utilization of Technology at KESBANGPOL

\begin{tabular}{|c|c|c|c|}
\hline No. & Group & Type & total \\
\hline \multirow[t]{8}{*}{1.} & HARDWARE: & & \\
\hline & $P C$ & \multirow{2}{*}{ Pentium IV, dual core and core i3. } & 23 Units \\
\hline & LAPTOP & & 10 Units \\
\hline & INPUT DEVICE & Scaner & 1 \\
\hline & OUTPUT DEVICE & Print & 20 \\
\hline & STORAGE & Hard drive & 23 \\
\hline & NETWORK & LAN, Wifi Access Point & 23,2 \\
\hline & TELEPHONE & FAX, Handy Talky & 2,34 \\
\hline \multirow[t]{6}{*}{2.} & SOFTWARE: & & \\
\hline & $\begin{array}{l}\text { OPERATING } \\
\text { SYSTEM }\end{array}$ & Win Xp sp 2, Win 7, & 23,23 \\
\hline & $\begin{array}{l}\text { WORD } \\
\text { OPERATION }\end{array}$ & Ms Word 2007, 2013 & 11,12 \\
\hline & SPREAD SHEET & Ms Excel 2007, 2013 & 11,12 \\
\hline & DATABASE & Ms Access 2007, 2013 & 23,23 \\
\hline & $\begin{array}{l}\text { SECURITY } \\
\text { GUARD }\end{array}$ & Smadav, AVIRA Free & 23,23 \\
\hline
\end{tabular}

The network condition of KESBANGPOL is shown in Picture 6 below :

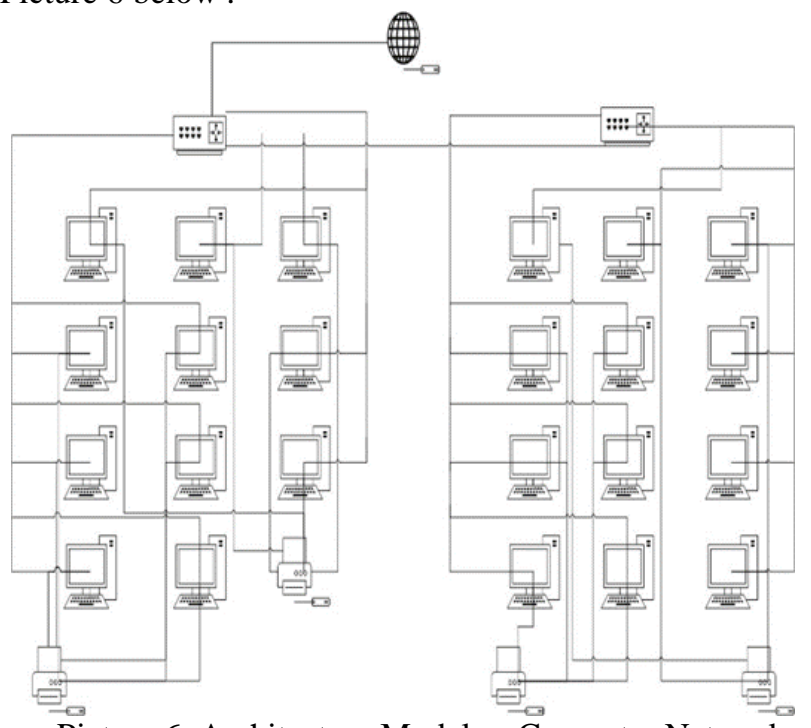

Picture 6. Architecture Model or Computer Network Topology in KESBANGPOL
Picture 6 illustrates the condition of the computer network owned by KESBANGPOL where there is 1 Internet-connected to 1 server. 1 The server is connected to 2 Routers, where 2 Routers are connected to 23 PC Servers and also connected to 20 printers.

Based on the application system architecture shown in Picture 7, a mapping process of infrastructure components can be carried out which refers to the TOGAF Technical Reference Model (TRM).

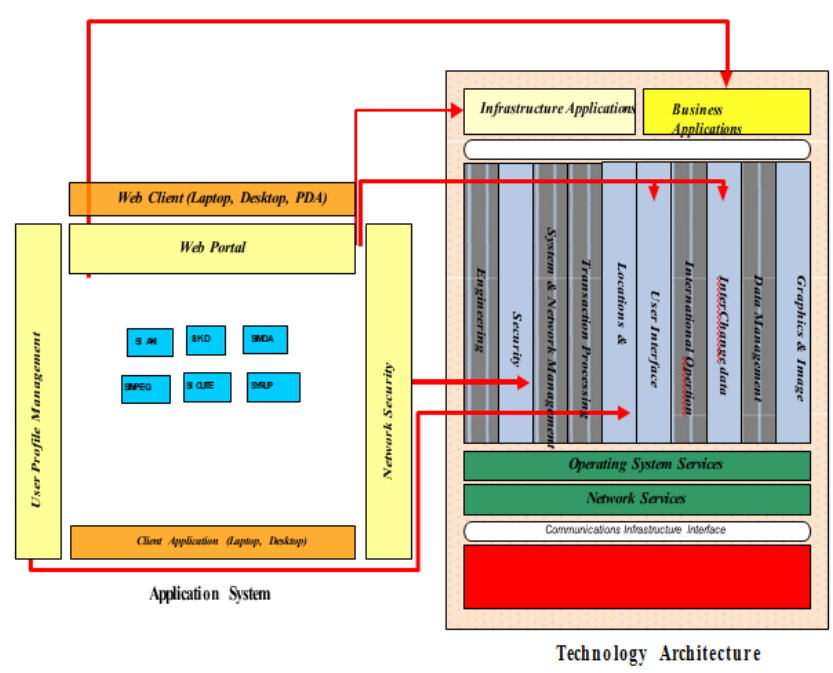

Picture 7. Mapping Application System Architecture to Technology Architecture

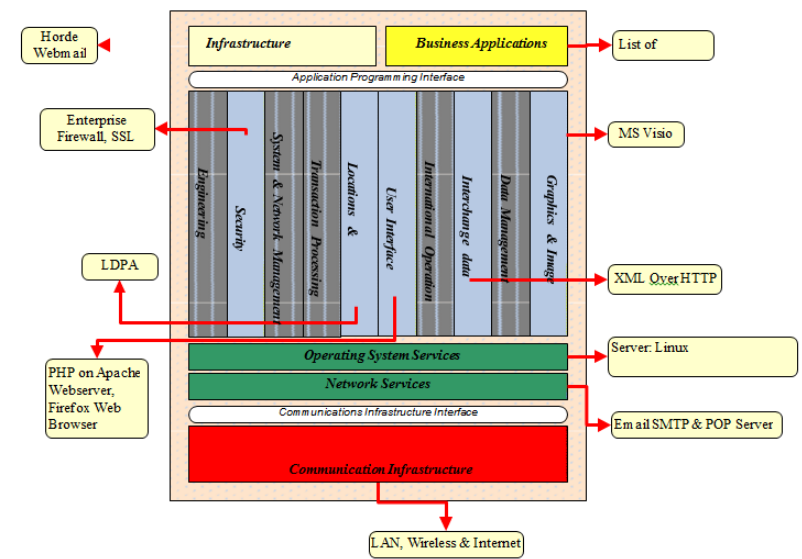

Picture 8. Mapping Infrastructure Component

Based on the mapping of the application system architecture to the technology architecture shown in Picture 7 and referring to the infrastructure components used in the mapping as shown in Figure 8, the overall architecture can be made which can be seen in Picture 9 following GAP Analysis. 


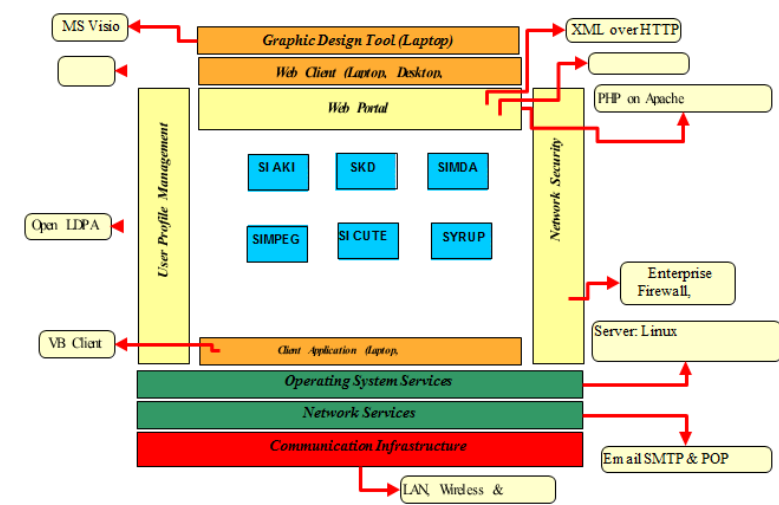

Picture 9. Overall Architecture

The following in Table 4 is an overview and analysis of gaps in the spaces and fields in KESBANGPOL. This description is seen based on 3 (three) components, namely applications, infrastructure, and human resources.

Table 4. GAP analysis of the KESBANGPOL information system

\begin{tabular}{|c|c|c|c|}
\hline $\begin{array}{l}\text { Space and } \\
\text { Field }\end{array}$ & IT Resources & Present condition & The expected conditions \\
\hline \multirow[t]{3}{*}{ Secretariat } & Application & There is no information system yet. & $\begin{array}{l}\text { There is an information system capable of managing } \\
\text { administration. }\end{array}$ \\
\hline & Infrastructure & There is no infrastructure yet. & $\begin{array}{l}\text { There is infrastructure and CCTV to support other information } \\
\text { systems. }\end{array}$ \\
\hline & Human Resources & $\begin{array}{l}\text { Security and supervision are still } \\
\text { lacking. }\end{array}$ & $\begin{array}{l}\text { There is an information system and human resources capable } \\
\text { of operating the information system. As expected and } \\
\text { maximum security. }\end{array}$ \\
\hline \multirow[t]{3}{*}{ Politics } & Application & $\begin{array}{l}\text { 1. Political education activities by } \\
\text { inviting speakers from academia, } \\
\text { KPU, and Kesbang. } \\
\text { 2. Political party financial assistance } \\
\text { activities are carried out manually. } \\
\text { 3. Election / pilkada facilitation } \\
\text { coordinates with the team. }\end{array}$ & $\begin{array}{l}\text { 1. There are several ways to do political education activities, } \\
\text { namely: through social media. } \\
\text { Political Party financial assistance requirements online. } \\
\text { 2. There needs to be coordination with Stake Holders and } \\
\text { related agencies. }\end{array}$ \\
\hline & Infrastructure & Less complete. & There needs to be a complete infrastructure. \\
\hline & Human Resources & $\begin{array}{l}\text { 1. There is } 1 \text { Head. } \\
\text { 2. There are } 1 \text { Sub. Dept. } \\
\text { 3. There are } 2 \text { staff / employees. } \\
\text { 4. Lack of staff so that work is not } \\
\text { optimal. }\end{array}$ & There needs to be additional staff / employees. \\
\hline \multirow{3}{*}{$\begin{array}{c}\text { Field of } \\
\text { Resilience } \\
\text {, Arts, } \\
\text { Culture, } \\
\text { Religion } \\
\text { and } \\
\text { People } \\
\text { Organizati } \\
\text { ons }\end{array}$} & Application & $\begin{array}{l}\text { There is no information system for } \\
\text { the administration of registration or } \\
\text { registered letters of ORMAS in the } \\
\text { City of Salatiga. }\end{array}$ & System for online Prmas registration. \\
\hline & Infrastructure & Inadequate infrastructure. & $\begin{array}{l}\text { Existing infrastructure must be improved so that activities in } \\
\text { the office are easier to carry out. }\end{array}$ \\
\hline & Human Resources & $\begin{array}{l}\text { Lack of Human Resources, so that } \\
\text { some jobs have to be delayed } \\
\text { because they are waiting for the } \\
\text { previous task to be completed. }\end{array}$ & The number of human resources added. \\
\hline \multirow[t]{3}{*}{$\begin{array}{l}\text { Ideology } \\
\text { and } \\
\text { National } \\
\text { Insights }\end{array}$} & Application & $\begin{array}{l}\text { 1. There is no information system } \\
\text { yet, so it only uses Microsoft } \\
\text { office word and excel. } \\
\text { 2. There is no information system } \\
\text { that can manage administrative } \\
\text { data }\end{array}$ & $\begin{array}{l}\text { 1. There is an information system capable of managing } \\
\text { administration. } \\
\text { 2. There is an adequate information system. }\end{array}$ \\
\hline & Infrastructure & $\begin{array}{l}\text { Facilities and infrastructure such as } \\
\text { laptops and } \mathrm{AC} \text { are not sufficient (1 } \\
\text { laptop) there is no AC. }\end{array}$ & $\begin{array}{l}\text { Every civil servant has at least } 1 \text { laptop and the room must } \\
\text { have air conditioning. }\end{array}$ \\
\hline & Human Resources & $\begin{array}{l}\text { 1. There is } 1 \text { Head. } \\
\text { 2. There are } 1 \text { Sub. Dept. } \\
\text { 3. There are } 2 \text { staffs. }\end{array}$ & $\begin{array}{l}2 \text { Sub. Dept. Minimal is supported by existing IT staff in order } \\
\text { to support tasks. }\end{array}$ \\
\hline
\end{tabular}




\begin{tabular}{|l|l|l|l|}
\hline $\begin{array}{c}\text { National } \begin{array}{c}\text { Vigilance } \\
\text { Sector }\end{array} \\
\text { Infrastructure }\end{array}$ & $\begin{array}{l}\text { Application } \\
\text { 2. Using the PSKP application } \\
\text { (Request for Research Certificate). } \\
\text { and society. }\end{array}$ & $\begin{array}{l}\text { 1. The PSKP application (Application for Research } \\
\text { Certificate) can be opened immediately in order to provide } \\
\text { convenience to the community. } \\
\text { 2. Work gets better, and faster. }\end{array}$ \\
\cline { 2 - 4 } & Human Resources available. & $\begin{array}{l}\text { There are CCTV and other information system supporting } \\
\text { infrastructure. }\end{array}$ \\
\cline { 2 - 4 } & $\begin{array}{l}\text { 1. There are 2 Computer Scholars. } \\
\text { 2. There is 1 Head. } \\
\text { 3. There are 1 Sub. Dept. } \\
\text { Maximum security. } \\
\text { Security oversight in the National } \\
\text { Vigilance Sector has not been } \\
\text { maximal. }\end{array}$ & \\
\hline
\end{tabular}

\section{CONCLUSION}

Based on this research it was found that there was no adequate administrative information system. The condition of the computer network owned by KESBANGPOL has 1 internet-connected to 1 server. 1 server is connected to 2 routers, where 2 routers are connected to 23 PC servers and also connected to 20 printers. Based on the application system architecture, the mapping process of infrastructure components can be carried out. These infrastructure facilities are still inadequate for KESBANGPOL with community service activities in Salatiga city which are very dense, so it is necessary to add computer and PC networks in order to facilitate service activities.

Suggestions for future development are that further research is needed on the strategic planning of information systems and information technology so that they become a reference for the development of business processes, information systems, and technology in stages and are gradually developed and maximized.

\section{REFERENCES}

AlSoufi, A. (2012). Bahrain National Enterprise Architecture Framework: a Platform towards a GCC EA Initiative. GSTF Journal on Computing, 2(1).

Hidayat, M. (2017). Penyusunan Rencana Strategis SIstem Informasi STKIP PGRI Banjarmasin Menggunakan Enterprise Architecture Planning. Jurnal Teknologi Rekayasa, 2(2), 63-72.

Irmayanti, D., \& Permana, B. (2018). Perencanaan Arsitektur Enterprise Sistem Informasi Disnakersostrans Kabupaten Purwakarta Menggunakan TOGAF. Jurnal Teknologi Rekayasa, 3(1), 17-28.

Kurniawan, Bobi. (2011). "Enterprise architecture planning sistem informasi pada perguruan tinggi swasta dengan zachman framework." Majalah Ilmiah UNIKOM.

Krisetya, N., Cahyono, A. D., \& Latuperissa, R. (2014). Penerapan Enterprise Architecture Planning (EAP) Pada Pembuatan Arsitektur Data, Aplikasi dan Teknologi (Studi Kasus: PT. Sumber Sehat).

Kustiyahningsih, Y. (2013). Perencanaan Arsitektur Enterprise Menggunakan Metode TOGAF ADM (Studi Kasus: RSUD Dr. Soegiri Lamongan).
In Prosiding Seminar Nasional Manajemen Teknologi XVIII (Vol. 27).

Subagio, R. T. (2017). Pemodelan Arsitektur Enterprise STMIK CIC Cirebon Menggunakan Enterprise Architecture Planning (EAP). Jurnal Digit, 1(2).

Suryana, T. (2012). Perancangan Arsitektur Teknologi Informasi dengan Pendekatan Enterprise Architecture Planning. Majalah Ilmiah UNIKOM.

Tyas, T. S., \& Tarmuji, A. (2013). Perancangan Enterprise Architecture Planning (EAP) Pada Proses Manajemen Aset Dengan Zachman Framework (Studi Kasus Divisi Manajemen Fasilitas PT. XYZ) (Doctoral dissertation, Universitas Ahmad Dahlan).

Utomo, A. P. (2014). Pemodelan arsitektur enterprise sistem informasi akademik pada perguruan tinggi menggunakan Enterprise Architecture Planning. Simetris: Jurnal Teknik Mesin, Elektro dan Ilmu Komputer, 5(1), 33-40. 